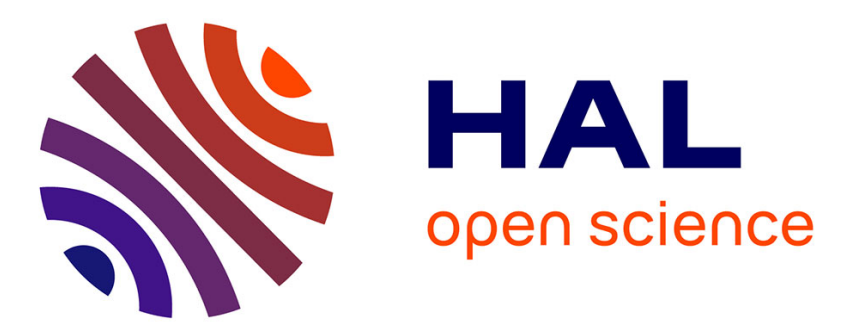

\title{
A passivity-based controller with charge estimation for coordination of converters in a fuel cell System; experimental results
}

Mickaël Hilairet, Malek Ghanes, Olivier Béthoux, Valentin Tanasa, Jean-Pierre Barbot, Dorothée Normand-Cyrot

\section{To cite this version:}

Mickaël Hilairet, Malek Ghanes, Olivier Béthoux, Valentin Tanasa, Jean-Pierre Barbot, et al.. A passivity-based controller with charge estimation for coordination of converters in a fuel cell System; experimental results. Power Plant and Power Systems Control symposium, Sep 2012, Toulouse, France. hal-03223611

\section{HAL Id: hal-03223611 \\ https://hal.science/hal-03223611}

Submitted on 11 May 2021

HAL is a multi-disciplinary open access archive for the deposit and dissemination of scientific research documents, whether they are published or not. The documents may come from teaching and research institutions in France or abroad, or from public or private research centers.
L'archive ouverte pluridisciplinaire HAL, est destinée au dépôt et à la diffusion de documents scientifiques de niveau recherche, publiés ou non, émanant des établissements d'enseignement et de recherche français ou étrangers, des laboratoires publics ou privés. 


\title{
A passivity-based controller with charge estimation for coordination of converters in a fuel cell System; experimental results
}

\author{
M. Hilairet*, M. Ghanes **, O. Béthoux* V. Tanasa ${ }^{* * *}$ \\ J-P. Barbot ${ }^{* *}$ D. Normand-Cyrot ${ }^{* * *}$ \\ * LGEP/SPEE Labs; CNRS UMR850\%; SUPELEC; Univ Pierre et \\ Marie Curie-P6; Univ Paris Sud-P11, 91192 Gif sur Yvette, France \\ ** ECS-Lab/ENSEA, Avenue du Ponceau, 95014 Cergy-Pontoise, \\ France \\ *** L2S; CNRS UMR 8506; SUPELEC; Université Paris-Sud 11; \\ 3, rue Joliot Curie, Plateau de Moulon F91192 Gif sur Yvette \\ e-mail: mickael.hilairet@lgep.supelec.fr
}

\begin{abstract}
The problem of power management of a fuel cell system involving a hydrogen fuel cell with supercapacitors for applications with high instantaneous dynamic power is addressed in this paper. The design of the controller is based on the interconnection and damping assignment - passivity based control. This control strategy is well adapted but requires the load resistance value in real-time. As, in practical applications the load resistance is an unknown physical variable, a load resistance estimation is added in order to manage accurately the power flow and the fuel cell current dynamic. Experimental results are presented demonstrating that this alternative approach is viable.
\end{abstract}

Keywords: Fuel cell, supercapacitors, port-controlled Hamiltonian systems, IDA-PBC methodology, load charge estimation, experimentation.

\section{INTRODUCTION}

To comply with environmental norms, development of electric and hybrid vehicles is increasing since 2009. In this context, the development of fuel cell (FC) system based on proton exchange membrane as the main energy source is considered. The combination of hydrogen and FC can increase the power and driving range of the vehicles. However, to ensure a good health of the FC, it is necessary that the FC delivers a slowly varying current, no more than $4 \mathrm{~A} / \mathrm{s}$ for a $0.5 \mathrm{~kW} / 12.5 \mathrm{~V}$ FC (Thounthong et al., 2009), and $10 \mathrm{~A} / \mathrm{s}$ for a $20 \mathrm{~kW} / 48 \mathrm{~V} \mathrm{FC} \mathrm{(Corbo} \mathrm{et} \mathrm{al.,} \mathrm{2009)} \mathrm{as}$ example.

Thus, a FC needs to be associated with other sources which provide the short pulse energy and fill the temporary failure of FC. Nowadays, these auxiliary sources can be either batteries or supercapacitors (SCs). But thermal constraints in automotive applications are severe and the requested braking power is even greater than the accelerating power. Sometimes batteries are not able to support this high power charge and discharge conditions, whereas supercapacitors can withstand high currents and operate even at low temperatures (e.g. -20C). Therefore, for fast car power demands, supercapacitors are probably the best suited components. At that point, the design challenge is to choose power components, to design an adapted architecture and also to define the appropriate associated control strategy (Giulii et al., 2004).

\footnotetext{
* This research was supported by the PEPS project "GESE : Gestion Echantillonnée des Systèmes Energétiques", 2010.
}

This article presents a permanent power source, transient and unidirectional power (the hydrogen fuel cell) assisted by a reversible impulse energy source (the supercapacitors). In this article, the parallel structure with two converters (see Fig. 1) is applied in order to manage the power flow (Tounthong et al., 2005).

This paper is organized into two sections as follows: section two describes a standard power management controller based on a frequency decoupling of the sources. The proposed passivity-based controller and a load charge estimation are detailed in section three; simulation and experimental results are presented in this section demonstrating that this alternative approach presented by simulation in (Hilairet et al., 2010; Hilairet and Bethoux, 2011) is viable.

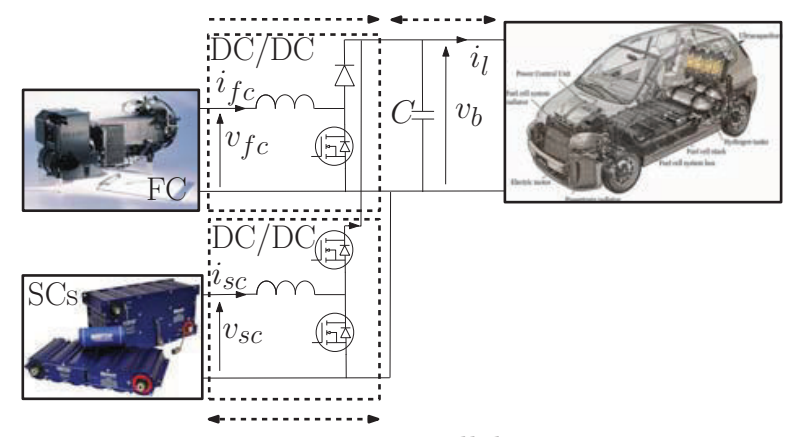

Fig. 1. Two converters in a parallel structure 


\section{POWER MANAGEMENT STRATEGIES}

A first control strategy of the two converters structure has been detailed in (Azib et al., 2011). It relies on the frequency decoupling of the sources according to the power demands. The DC bus capacitor filters the high frequencies (i.e. above the $\mathrm{kHz}$ ), the $\mathrm{SCs}$ associated with its converter provides the medium frequencies (from $\mathrm{kHz}$ to $\mathrm{Hz}$ ) and the FC ensures the low frequencies (less than $1 \mathrm{~Hz}$ ). This frequency decoupling of the sources naturally induces a power management strategy based on cascaded loops presented in Fig. 2.

Any power load modification induces a change in the DC bus voltage. Hence, it seems judicious to control the DC bus voltage with the SCs by computing the reference current $i_{s c}^{*}$, and thus regulate the bus voltage to its reference. The outer voltage loop associated with the SCs management must maintain the DC bus voltage at a constant reference $v_{b}^{*}$ fixed at $50 \mathrm{~V}$. The current loops are based on proportional-integral controller. Thus, the voltage closed-loop controller bandwidth is chosen ten times lower than the current closed-loop controller bandwidth.

Nevertheless, the DC bus request for assistance would result in a permanent discharge of $\mathrm{SCs}$, which would impose them an excessive capacity to continuously provide and absorb power during fast transients. Therefore, the control system must maintain, in steady state, the SCs state of charge at a desired value and avoid huge SCs voltage ripple. This requirement can be ensured by a

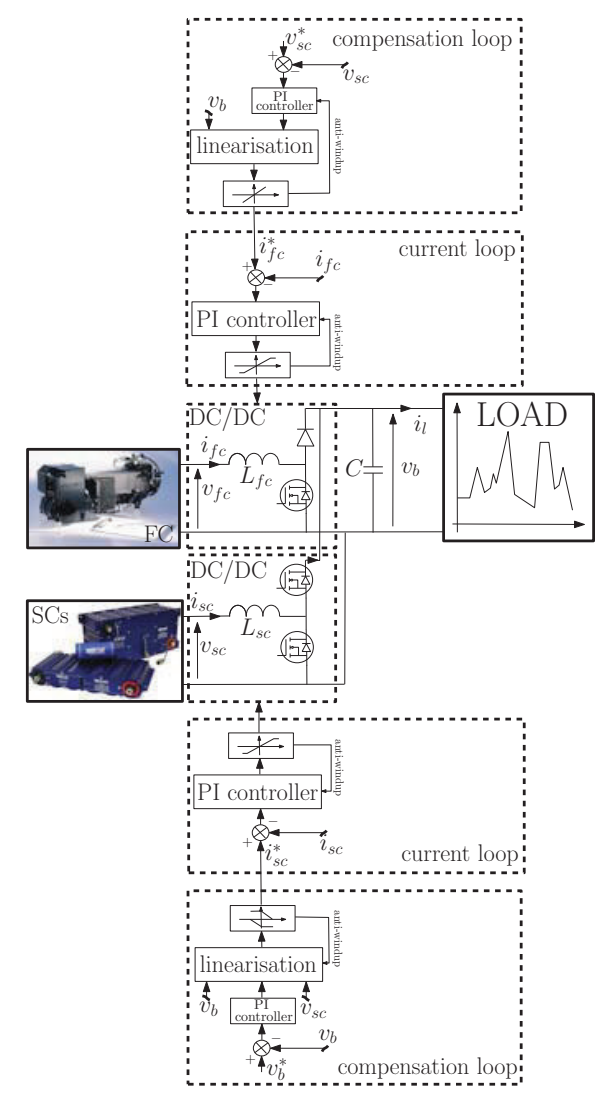

Fig. 2. Block diagram of the first control strategy. compensation loop whose purpose is to regulate the SCs voltage $v_{s c}$ at their references $v_{s c}^{*}$.

The compensation controller is a proportional-integral controller. Its bandwidth is chosen to meet the FC constraints; in our experimental setup, this parameter is approximatively tuned at $1 \mathrm{~Hz}$. Thus the compensation loop generates a current reference $i_{f c}^{*}$ with a slow dynamic. Moreover, the frequency bandwidth is much lower than the current loops and the DC voltage bus bandwidths. Consequently, this choice meets the frequency decoupling requirement and allows good control of the SCs to their voltage reference levels.

The frequency decoupling adopted in (Azib et al., 2011) validates the described approach and demonstrates a better efficiency than in the single unattended FC (Azib et al., 2009). The SCs provide power transient, while the current delivered by the FC is slowly varying in order to ensure its longevity. The gains are tuned to ensure practical closed loop system stability, although this property is not theoretically proved.

Therefore, an alternative solution consists in developing a linear or non-linear controller based on the same specifications but relying on theoritical proofs of stability. In this work, we have designed and experimentally validated a passivity-based controller; it proved to have many theoretical and practical advantages.

\section{PASSIVITY-BASED CONTROLLER}

\subsection{Controller structure}

One solution to design the energy flow controller can be based on the full non-linear system (see as example (Becherif, 2006)). However, such control does not guarantee that the current $i_{f c}$ and $i_{s c}$ are in a suitable bandwith, to protect the sources, the converters and the load.

Therefore, a classic solution consists in designing a cascaded control, as detailed in the previous paragraph. Fig. 3 represents the controller adopted in this work. It is composed of three subsystems : an inner current loop controller for the FC based on a PI controller, an inner

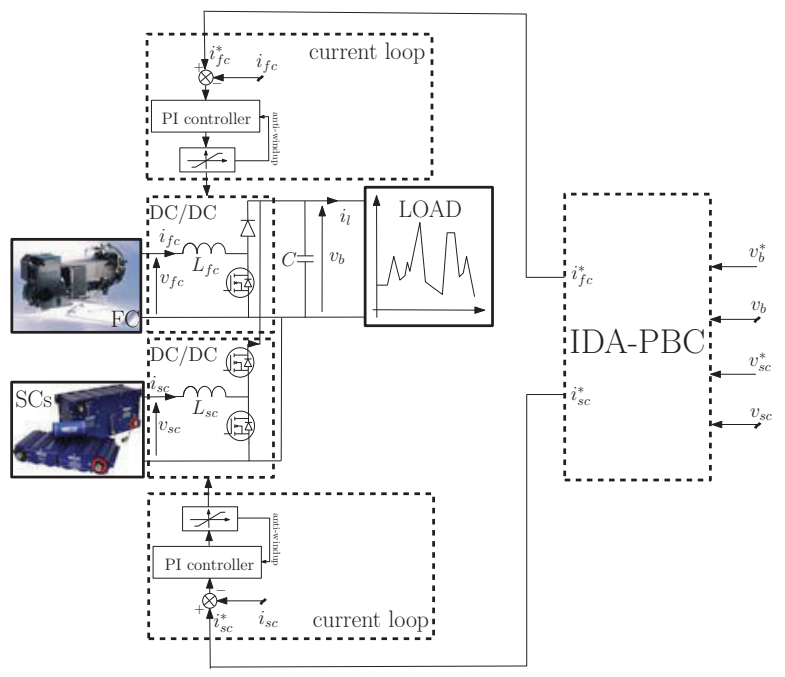

Fig. 3. Block diagram of the IDA-PBC controller. 
current loop controller to manage the current of the SCs based on a PI controller, and an only outer loop to control both the DC bus voltage and the SCs state of charge.

\subsection{Hybrid system modeling}

Fuel cell modeling The model used is a static model, where the $\mathrm{FC}$ voltage $v_{f c}$ is computed according to the current stack $i_{f c}$. The FC voltage $v_{f c}$ is represented by a $5^{\text {th }}$ order polynomial function of the stack current $i_{f c}$.

$F C$ boost converter The boost converter represented in the Fig. 4 has the binary input $w_{1}(t)$ as control input. Defining $\alpha_{1}$ as the duty cycle of the control variable $w_{1}(t)$, this subsystem can be represented by its average model :

$$
\frac{d i_{f c}}{d t}=\frac{1}{L_{f c}}\left(-\left(1-\alpha_{1}\right) v_{b}+v_{f c}\right)
$$

SCs buck-boost converter The storage elements connection on the DC bus are made with reversible power static converters, allowing SCs to be loaded or unloaded. In our experimental setup, the SCs have a constant capacity $C_{s c}$ and negligible losses. They are associated with an inductance $L_{s c}$ and an elementary switching cell as shown in Fig. 4. This cell current is bi-directional. Two types of operation are possible : a buck operating mode corresponding to SCs receiving energy from the DC bus, and a boost operating mode when SCs provide energy to the DC bus. We define $\alpha_{2}$ the duty cycle of the binary control variable $w_{2}(t)$. The average model of the second sub-system is represented by the two following equations:

$$
\begin{aligned}
\frac{d i_{s c}}{d t} & =\frac{1}{L_{s c}}\left(-\left(1-\alpha_{2}\right) v_{b}+v_{s c}\right) \\
\frac{d v_{s c}}{d t} & =-\frac{i_{s c}}{C_{s c}}
\end{aligned}
$$

$D C$ bus and load model Fig. 4 shows also the model of the DC bus and the load. In our work, the load is modeled by a $\left(R_{l} L_{l}\right)$ circuit, whose resistance value $R_{l}$ varies depending on the power demanded by the load. The average model is:

$$
\begin{aligned}
\frac{d v_{b}}{d t} & =\frac{1}{C}\left(\left(1-\alpha_{1}\right) i_{f c}+\left(1-\alpha_{2}\right) i_{s c}-i_{l}\right) \\
\frac{d i_{l}}{d t} & =\frac{1}{L_{l}}\left(-R_{l} i_{l}+v_{b}\right)
\end{aligned}
$$

Complete model To sum up, a $5^{\text {th }}$ order non-linear state space model describes the complete system "fuel cell supercapacitors" :

$$
\begin{aligned}
\dot{x}_{1}(t) & =\frac{\left(1-\alpha_{1}(t)\right) x_{4}(t)+\left(1-\alpha_{2}(t)\right) x_{5}(t)-x_{3}(t)}{C} \\
\dot{x}_{2}(t) & =-\frac{x_{5}(t)}{C_{s c}} \\
\dot{x}_{3}(t) & =\frac{-R_{l} x_{3}(t)+x_{1}(t)}{L_{l}} \\
\dot{x}_{4}(t) & =\frac{-\left(1-\alpha_{1}(t)\right) x_{1}(t)+z}{L_{f c}} \\
\dot{x}_{5}(t) & =\frac{-\left(1-\alpha_{2}(t)\right) x_{1}(t)+x_{2}(t)}{L_{s c}}
\end{aligned}
$$

with the state space $x(t)=\left[x_{1} ; x_{2} ; x_{3} ; x_{4} ; x_{5}\right]^{t}=$ $\left[v_{b} ; v_{s c} ; i_{l} ; i_{f c} ; i_{s c}\right]^{t}$, the control inputs $u(t)=\left[u_{1} ; u_{2}\right]^{t}=$ $\left[1-\alpha_{1} ; 1-\alpha_{2}\right]^{t}$, the measures $y(t)=x$ and $z(t)=v_{f c}$.

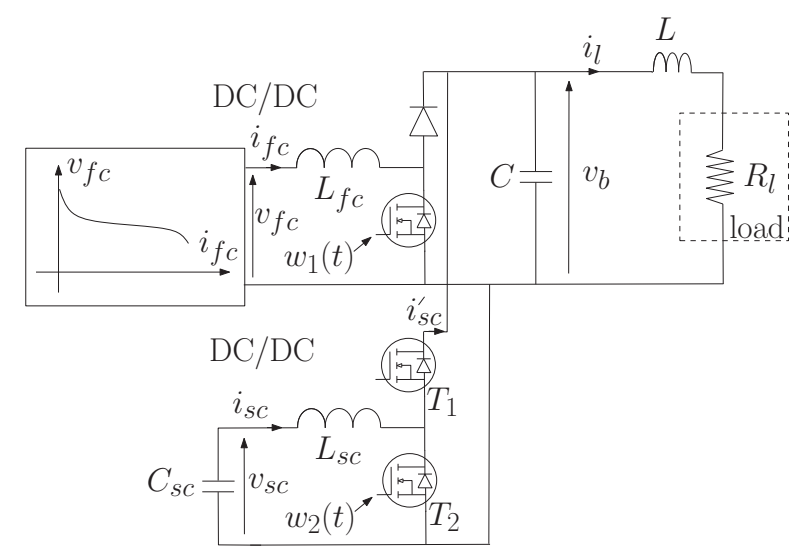

Fig. 4. FC boost converter, SCs buck-boost converter, DC bus and load model.

\subsection{Outer closed loop control}

The currents control is provided by two fast inner loops, so we can assume that the currents are equal to their references according to the voltage time scale. Under these conditions, the $5^{\text {th }}$ order system (4) can be reduced to a $3^{\text {th }}$ order system, whose state equation is given below :

$$
\begin{aligned}
& \dot{x}_{1}(t)=\frac{1}{C}\left(\frac{z_{3}(t)}{x_{1}(t)} u_{1}(t)+\frac{x_{2}(t)}{x_{1}(t)} u_{2}(t)-x_{3}(t)\right) \\
& \dot{x}_{2}(t)=-\frac{u_{2}(t)}{C_{s c}} \\
& \dot{x}_{3}(t)=\frac{-R_{l} x_{3}(t)+x_{1}(t)}{L_{l}}
\end{aligned}
$$

with $x(t)=\left[x_{1} ; x_{2} ; x_{3}\right]^{t}=\left[v_{b} ; v_{s c} ; i_{l}\right]^{t}$, the control inputs $u=\left[u_{1} ; u_{2}\right]^{t}=\left[i_{f c} ; i_{s c}\right]^{t}$ and the measures $y=$ $\left[v_{b} ; v_{s c} ; i_{l}\right]^{t}$ and $z=\left[i_{f c} ; i_{s c} ; v_{f c}\right]^{t}$, with the desired equilibrium point $\bar{x}=\left[\bar{x}_{1} ; \bar{x}_{2} ; \bar{x}_{3}\right]=\left[v_{b}^{*} ; v_{s c}^{*} ; \frac{v_{b}^{*}}{R_{l}}\right]$, with $v_{b}^{*}$ and $v_{s c}^{*}$ the DC bus and SCs desired voltages, and the storage function $H(x)=\frac{1}{2} x^{t} Q x$ with $Q=\operatorname{diag}\left(C ; C_{s c} ; L_{l}\right)$.

Remark 1 : It is important to note that the model (5) is only valid if all its outer closed loop dynamic are slower than the dynamic of the fast actuator, here the PI controler which assign currents $i_{f c}$ and $i_{s c}$.

\subsection{PCH model of the outer-loop control}

We look for an energy function $H(x)$ so that its minimum is reached at the desired equilibrium point $\bar{x}$ (Ortega and Garcia-Canseco, 2004; Batlle et al., 2009). Also, a choice of the energy function $H$ is :

$$
H_{d}=\frac{1}{2} \tilde{x(t)}{ }^{t} Q \tilde{x(t)} \quad \text { with } \quad \tilde{x}(t)=x(t)-\bar{x}(t)
$$

In these circumstances, writing the $\mathrm{PCH}$ system (5) in terms of the dynamics of the error and the gradient of the closed-loop desired energy function $\nabla H_{d}$ is:

$$
\dot{\tilde{x}}(t)=[\mathcal{J}-\mathcal{R}] \nabla H_{d}+A(u(t), \bar{x}(t))
$$

with

$$
\mathcal{J}-\mathcal{R}=\left[\begin{array}{ccc}
0 & 0 & -\frac{1}{L_{l} C} \\
0 & 0 & 0 \\
\frac{1}{L_{l} C} & 0 & -\frac{R_{l}}{L_{l}^{2}}
\end{array}\right], \quad \nabla H_{d}=\left[\begin{array}{c}
C \tilde{x}_{1} \\
C_{s c} \tilde{x}_{2} \\
L_{l} \tilde{x}_{3}
\end{array}\right]
$$


$A(u, x, \bar{x}, z)=\left[\begin{array}{c}\frac{1}{C}\left(\frac{z_{3}(t)}{x_{1}(t)} u_{1}(t)+\frac{x_{2}(t)}{x_{1}(t)} u_{2}(t)-\bar{x}_{3}(t)\right) \\ -\frac{1}{C_{s c}} u_{2}(t) \\ 0\end{array}\right]$

\subsection{IDA-PBC controller equation}

The following control laws have been proposed (Hilairet et al., 2010; Hilairet and Bethoux, 2011):

$$
\begin{aligned}
& u_{1}(t)=\frac{x_{1}(t)}{z_{3}(t)}\left(\frac{\bar{x}_{1}(t)}{R_{l}(t)}-\alpha \tilde{x}_{2}(t)\right) ; \quad \alpha>0 \\
& u_{2}(t)=-\alpha \tilde{x}_{1}(t)
\end{aligned}
$$

so that the closed-loop system is as follows:

$$
\dot{\tilde{x}}(t)=\left[\mathcal{J}_{d}-\mathcal{R}_{d}\right] \nabla H_{d}
$$

with

$$
\mathcal{J}_{d}=\left[\begin{array}{ccc}
0 & -\frac{\alpha}{C C_{s c}} & -\frac{1}{L_{l} C} \\
\frac{\alpha}{C C_{s c}} & 0 & 0 \\
\frac{1}{L_{l} C} & 0 & 0
\end{array}\right], \quad \mathcal{R}_{d}=\left[\begin{array}{ccc}
\frac{x_{2} \alpha}{x_{1} C^{2}} & 0 & 0 \\
0 & 0 & 0 \\
0 & 0 & \frac{R_{l}}{L_{l}^{2}}
\end{array}\right]
$$

The proof of asymptotic stability is deduced from the derivative analysis of $H_{d}$ :

$$
\dot{H}_{d}=\nabla H_{d}^{t} \dot{\tilde{x}}=-\nabla H_{d}^{t} R_{d} \nabla H_{d}^{t} \leq 0
$$

and the invariance principle of the LaSalle theorem with $H_{d}(\bar{x})=\dot{H}_{d}(\bar{x})=0$. Moreover, $H_{d}$ is radially unbounded, therefore the closed-loop system (voltages control) is globally asymptotically stable.

Finally, according to the Tikhonov's theorem, we can demonstrate (see Ghanes et al. (2011)) that the whole system is locally asymptotically stable because the outer closed loop dynamic are slower than the dynamic of the fast actuator, here the PI controller which assign currents $i_{f c}$ and $i_{s c}$.

The control equation analysis shows that SCs provide the energy due to an error on the DC bus voltage, the error itself is caused by power spikes or a variation of the DC bus voltage reference. The desired current $u_{1}=i_{f c}^{*}$ shows that the FC keeps up with the two main objectives :

- the permanent power flow from the FC to the load,

- the energy contribution to regulate the SCs voltage.

\subsection{Simulation results}

Equa. (10) shows that the proposed controller requires the knowledge of the load resistance $\left(R_{l}\right)$ for computing of the FC reference current. To explain the implementation design procedure, we first consider an control algorithm without any information about the the load : the FC reference current computation is based on a constant and arbitrary value of the load resistance $\left(R_{l}\right)$. This first case is refered as "case of a unknown load charge". In a second step, the load is considered as an unknown variable and a load resistance estimation scheme is added in order to compute this variable in real-time. This second case is refered as "case of load charge estimation".
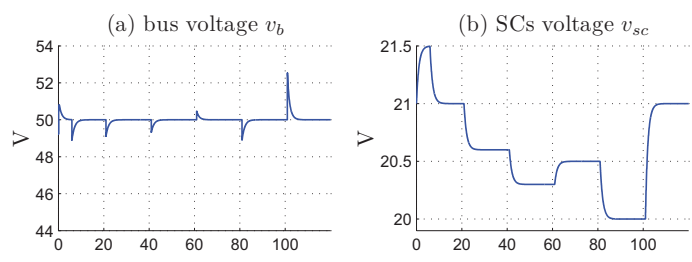

(c) load current $i_{L}$

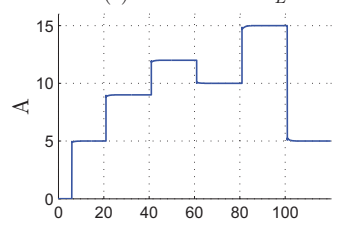

(d) fuel cell voltage $v_{f c}$

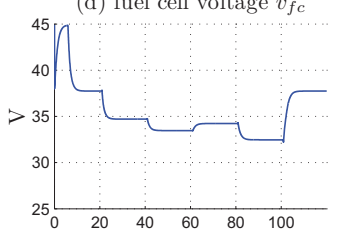

(e) fuel cell current $i_{f c}$

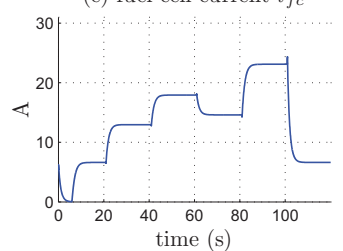

(e) SCs current $i_{f c}$

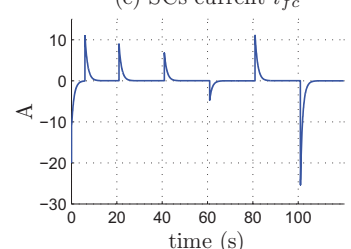

Fig. 5. Simulation result without an integral action or a load charge estimation $(\alpha=10)$.

Case of a unknown load charge Fig. 5 represents a scenario where the reference DC bus voltage is set equal to $50 \mathrm{~V}$ and the load current varies between 0 and $15 \mathrm{~A}$.

Fig. 5.a shows that the control ensures perfect control of the DC bus voltage, the SCs respond rapidly to fast current transient to provide most of the power required by the load and to maintain the $\mathrm{DC}$ bus voltage at its reference value. This allows the $\mathrm{FC}$ to have a smooth response during fast power demand of the load (Fig. 5.e), what improves his state of health. Then gradually with the FC current increasement, the SCs discharge, characterized by the decrease of its voltage, vanishes to zero (see Fig. 5.e).

The SCs voltage is however not regulated to the reference value equal to $21 \mathrm{~V}$, and depends on the load power since the IDA-PBC controller assumes the load resistor as constant (the arbitrary admittance used in the controller equation is equal to $5 \mathrm{~A} / 50 \mathrm{~V}=0.1 \mathrm{~S})$. Under these conditions, SCs provide too much energy during the power transition and SCs recharging is uncertain.

To overcome this problem, two solutions have been explored. First, a low integrator action has been added to the command value $u_{1}=i_{f c}^{*}$ (Hilairet et al., 2010; Tiefensee et al., 2010). Second, a load resistance estimation eliminates this error (Hilairet and Bethoux, 2011). This article deals with this second approach and shows experimental results of its implementation.

Case of load charge estimation As noticed before, in practical applications the load resistance is obviously unknown. In this paragraph a load estimator is considered as another way to cope with this problem. The admittance $\left(Y_{k}=1 / R_{l k}\right)$ of the load is estimated as follows: 
(a) simulation

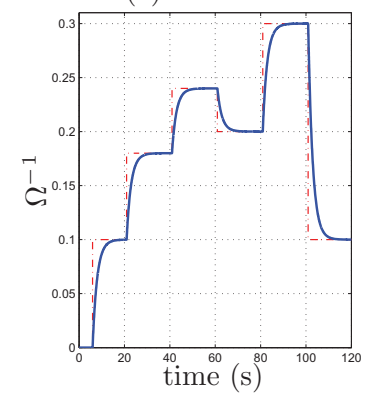

(b) experimental

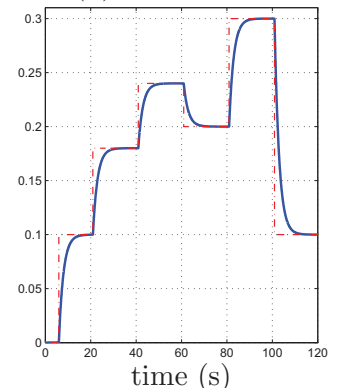

Fig. 6. Simulation and experimental results of the load estimator $\left(K_{R l}=0.5\right)$.

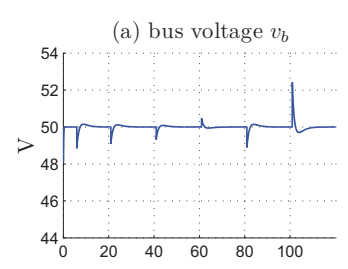

(c) load current $i_{L}$

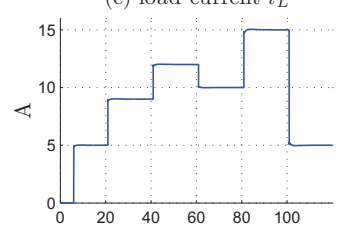

(e) fuel cell current $i_{f c}$
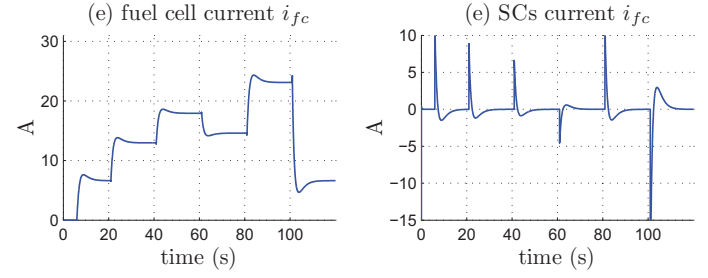

(d) fuel cell voltage $v_{f c}$

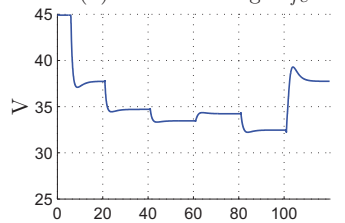

(e) SCs current $i_{f c}$

Fig. 7. Simulation of the linear controller with the load resistance estimation $\left(\alpha=10, K_{R l}=0.5\right)$.

$$
Y_{k}=e^{-K_{R l} T_{e}} Y_{k-1}+\left(1-e^{-K_{R l} T_{e}}\right) \frac{i_{l k}}{v_{b k}}
$$

where the tuning parameter $K_{R l}$ controls the sensibility of the fuel cell current reference and $T_{e}$ is the sample time.

Fig. 6 shows the estimator behaviour. The steady state error is null and the dynamic is monitored by the tuning parameters $K_{R l}$. In this application, gain $K_{R l}$ is selected in order to obtain a slow time response of about 6 s, so that the FC current reference reacts smoothly.

Fig. 7 depicts the global system performances. In this simulation the load resistance estimate is used in the controller. With the former observer parameter set $\left(K_{R l}=0.5\right)$, the $\mathrm{FC}$ current variation is less than $4 \mathrm{~A} / \mathrm{s}$. It indeed respects the FC specifications. This controller architecture also leads to a nearly zero static error of the SCs voltage without adding any integral action. Nevertheless, a low integral action needs to be added in a practical application to compensate for the converter losses.

\subsection{Experimental results}

The IDA-PBC controller has been experimentally validated on a hybrid test bench composed of a 46A/1200W Nexa Ballard fuel cell. The transient auxiliary source consists of two Maxwell SC modules associated in series: each module is achieved with the connection of six individual elements in series $[2.7 \mathrm{~V}, 350 \mathrm{~F}]$. This SCs device is interconnected to the DC bus using a chopper built with standard MOS modules and a switching frequency of the PWM set to $20 \mathrm{kHz}$.

The hybrid power source is connected to a programmable electronic load (Hcherl \& Hackl, model ZS1806), which has a rated power of $1800 \mathrm{~W}(\operatorname{Imax}=150 \mathrm{~A} / \mathrm{V} \max =60 \mathrm{~V})$. This load emulates vehicle power consumption, and is directly monitored by the dSPACE DS1103 real-time board. Finally, table 1 summarize the electric characteristics of the electrical system.

The current inner control loops, which generate both duty cycles $\alpha_{1}$ and $\alpha_{2}$, have been implemented with digital PI controllers updated at $20 \mathrm{kHz}$. The voltage outer control loops have a sampling time equal to $2 \mathrm{KHz}$.

Figs. 6 and 8 show the experimental results of the proposed controller. The reference DC bus voltage is set equal to $50 \mathrm{~V}$, and the load current varies between 0 and $15 \mathrm{~A}$. Note that the DC bus and SC voltages are well regulated in spite of the very fast dynamics of power demand. Each time the power load varies, SC current is positive (respectively negative) during an increase (respectively decrease) of the power load. In such situation, the SC voltage continuously fluctuates around its constant reference value $v_{S C}^{*}$ set to $21 \mathrm{~V}$, as shown in Fig. 8.b. However, we can note that the $\mathrm{SC}$ voltage is not perfectly equal to its reference at steady state. This is due to the FC converter losses.

\section{CONCLUSION}

In this paper, a new Energy Management Strategy to monitor the energy provided by two complementary power sources, namely a hydrogen fuel cell and supercapacitors, has been discussed. This control law based on passivity ensures local asymptotic stability of the whole closedloop system, while reducing the load stress on the stack power transients. In addition, this outer voltage controller has only 2 tuning parameters $\left(\alpha, K_{R l}\right)$ ), which makes the implementation on a real-time system easy.

As the controller needs the information on the load resistance, two alternative solutions have been proposed: to add an integral action (Hilairet et al., 2010; Tiefensee et al., 2010) or a load resistance estimation (Hilairet and Bethoux, 2011). In both cases the FC dynamic can be easily tuned while the SCs state of charge is well regulated in steady state. Simulation and experimental results are consistent, and the controller performances validate the proposal.

In a practical application, when the controller is implemented by a computer, the system is placed in a sampleddata context and, as it is well known, passivity properties are usually lost (S.Monaco et al., 2008). Consequently, passivity based controllers implemented through a zero order holder device (emulation process) loose their validity 

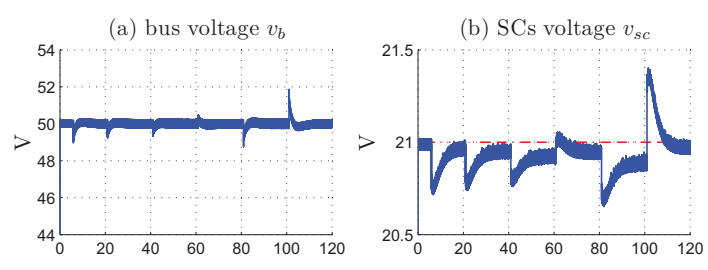

(c) load current $i_{L}$

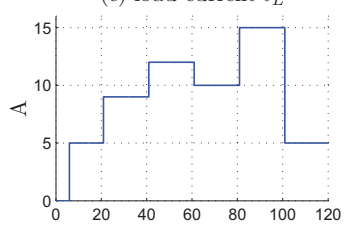

(d) fuel cell voltage $v_{f c}$

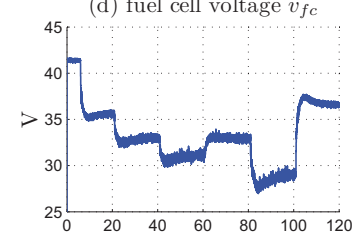

(e) fuel cell current $i_{f c}$
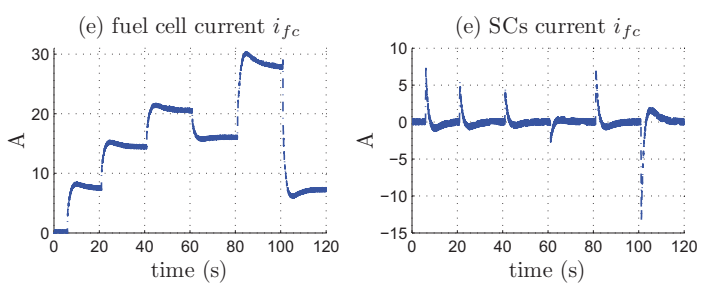

Fig. 8. Experimental result of the linear controller with the load resistance estimation $\left(\alpha=10, K_{R l}=0.5\right)$.

Table 1. Electric characteristics of the system.

\begin{tabular}{|c|r|}
\hline Fuel cell parameters & Value \\
\hline \hline Open circuit voltage E & $45 \mathrm{~V}$ \\
Rated voltage & $26 \mathrm{~V}$ \\
Rated current & $46 \mathrm{~A}$ \\
\hline \hline Supercapacitors parameters & \\
\hline \hline Capacitance & $26 \mathrm{~F}$ \\
Rated voltage & $30 \mathrm{~V}$ \\
Rated current & $200 \mathrm{~A}$ \\
Optimal voltage $\left(v_{s c}^{*}\right)$ & $21 \mathrm{~V}$ \\
\hline \hline Electric load parameters & \\
\hline Rated power & $1800 \mathrm{~W}$ \\
Rated voltage & $60 \mathrm{~V}$ \\
Rated current & $150 \mathrm{~A}$ \\
\hline \hline Inductance and capacitie parameters & \\
\hline \hline$L_{f c}$ inductance & $200 \mu \mathrm{H}$ \\
$L_{s c}$ inductance & $100 \mu \mathrm{H}$ \\
Rated current $L_{f c}$ & $100 \mathrm{~A}$ \\
Rated current $L_{s c}$ & $150 \mathrm{~A}$ \\
Capacities $C$ & $9 \mathrm{mF}$ \\
Optimal DC bus voltage $\left(v_{b}^{*}\right)$ & $50 \mathrm{~V}$ \\
\hline
\end{tabular}

(Tiefensee et al., 2010). This problem is often masked by the choice of a very small sampling period and/or very small controller gain value. However, this simplistic solution immediately reflects in unrealistic industrial requirements such as the necessity of expansive computers with remarkable capacity, slower system transient response (resulting in a less performing vehicle) and mainly the need of increasing current amplitudes. Therefore, in order to extend these works (Hilairet et al., 2010; Tiefensee et al., 2010; Hilairet and Bethoux, 2011), a future study could investigate the behaviour of the whole closed-loop system according the sampling-time value and design procedure.

\section{REFERENCES}

Azib, T., Bethoux, O., Marchand, C., and Berthelot, E. (2009). Supercapacitors for power assistance in hybrid power source with fuel cell. IEEE Industrial Electronics Society Conference IECON'09.

Azib, T., Bethoux, O., Remy, G., and Marchand, C. (2011). Saturation management of a controlled fuelcell/ultracapacitor hybrid vehicle. IEEE Transactions on Vehicular Technology, 60, 4127-4138.

Batlle, C., Doria-Cerezo, A., Espinosa-Perez, G., and Ortega, R. (2009). Simultaneous interconnection and damping assignment passivity-based control: The induction machine case study. Int. J. Control, 82(2), 241-255.

Becherif, M. (2006). Passivity-based control of hybrid sources : fuel cell and battery. $11^{\text {th }}$ IFAC Symposium on Control in Transportation Systems.

Corbo, P., Migliardinia, F., and Veneri, O. (2009). Pefc stacks as power sources for hybrid propulsion systems. International Journal of Hydrogen Energy, 34, 46354644.

Ghanes, M., Hilairet, M., Barbotand, J.P., and Bethoux, O. (2011). Singular perturbation control for coordination of converters in an fuel cell system. Electrimacs.

Giulii, F., Capponi, and Cacciato, M. (2004). Using super capacitors in combination with bi-directional $\mathrm{dc} / \mathrm{dc}$ converters for active load management in residential fuel cell applications. 1st European Symposium on Supercapacitors IEEE ESSCAP.

Hilairet, M. and Bethoux, O. (2011). A passive controllerobserver for coordination of converters in a fuel cell system. IEEE International Symposium on Industrial Electronics ISIE.

Hilairet, M., Bethoux, O., Azib, T., and Talj, R. (2010). Interconnection and damping assignment passivity-based control of a fuel cell system. IEEE International Symposium on Industrial Electronics ISIE.

Ortega, R. and Garcia-Canseco, E. (2004). Interconnection and damping assignment passivity-based control : a survey. European Journal of control, 10(432-450).

S.Monaco, Normand-Cyrot, D., and Tiefensee, F. (2008). From passivity under sampling to a new discrete-time passivity concept. 3157-3162.

Thounthong, P., Rael, S., and Davat, B. (2009). Energy management of fuel cell/battery/supercapacitor hybrid power source for vehicle applications. Journal of Power Sources, 193, 376-385.

Tiefensee, F., Hilairet, M., Normand-Cyrot, D., and Bethoux, O. (2010). Sampled-data energetic management of a fuel cell/supercapacitor system. IEEE Vehicle Power and Propulsion Conference VPPC.

Tounthong, P., Rael, S., and Davat, B. (2005). Supercapacitors as an energy storage for fuel cell automotive hybrid electrical system. International Journal of Electrical Engineering in Transportation, 1. 